\title{
California Partnership Law and the Uniform Partnership Act'
}

\section{INTRODUCTION}

T 1914 , after twelve years of discussion and the careful consideration of eight drafts and revisions, the Commissioners on Uniform State Laws of the American Bar Association approved and recommended for adoption a Uniform Partnership Act. In the next year the Act was made the law of Pennsylvania and Wisconsin; in 1916, of Maryland; in 1917, of Illinois, Michigan, Tennessee, Wyoming and Alaska; in 1918, of Virginia; and in 1919, of Idaho, New Jersey and New York, a total of eleven states and one territory in five years. ${ }^{2}$ In 1919 it also came up for adoption in California but never passed beyond the committee stage. ${ }^{3}$ It is extremely likely that it will be presented again at the next meeting of the legislature.

California has already adopted three acts, the work of the commissioners, namely, the Uniform Warehouse Receipts Act in $1909,{ }^{4}$ the Uniform Bills of Lading Act in 1919,5 and the Uniform Negotiable Instruments Act in 1917. ${ }^{6}$ The remaining twenty-seven uniform acts recommended by them remain unadopted in this state. Wisconsin has made twenty-one her law; no state, territory, or possession of the United States has failed to adopt at least one; and only Arkansas, Colorado, Florida, Georgia, Nebraska, Oklahoma, Porto Rico, South Carolina, Hawaii, and the District of Columbia, a total of ten out of fifty-three legislative units, have adopted fewer than ourselves. ${ }^{\text {T }}$ The movement towards uniformity in state laws is therefore very strong and cannot be ignored here, notwithstanding the fact that we, unlike some other states, have a code, complete in theory.

There are certainly strong arguments for adopting uniform state laws for no other reason than to make the laws of all states,

1 This article will be continued in the March number of the California Law Review. The author wishes to record his gratitude to Mr. I. A. Cereghino, of the School of Jurisprudence, for valuable assistance in its preparation.

2 Reports of American Bar Association, 1919, vol. XLIV, p. 553.

3 Senate Bill No. 132, introduced by Senator Sample, January 17, 1919, referred to Committee on Judiciary.

${ }^{4}$ Cal. Stats. 1909 , p. 437.

5 Cal. Stats. 1919, p. 762, now Civ. Code, $\$ \S 2126$ to $2132 d$.

- Cal. Stats. 1917, p. 1531, now Civ. Code, \$\$ 3082 to 3266d.

7 See reference in note 2 . 
territories, and possessions as far as possible alike. Those whose personal property and business interests bring them into contact with the laws of several states áre becoming more numerous, and with this increase the inconvenience that comes from a diversity of laws is growing greater. The only really effective force now at work to counteract this tendency and alleviate this inconvenience is that of the commissioners above mentioned. ${ }^{8}$ An act recommended by them should come to a state legislature with many presumptions in its favor. It should not fail of passage merely because it does not improve existing state law on the subject it covers, for its purpose is not so much to improve as to create uniformity, and the desirability of real uniformity is in itself enough to outweigh such lack of beneficial alteration in the law governing purely local matters.

It is suggested that the benefits to the community of uniformity in partnership law is greater than it was a few years ago. A man will not organize a corporation with the same lightheartedness of former days, for the corporation (to mix metaphors) has become the punching-bag of politicians showing their prowess, and the suckable orange of the tax collector. The partnership form for doing business is not yet so odious, and necessarily is more popular and desirable. Today more than yesterday, partnership enterprises, by no means small, conduct their affairs in several states.

It has been the policy of the CaLIFornia LAw Review to publish articles on various uniform state laws presented for adoption in this state. ${ }^{2}$ The present is one of the series. It is not an argument but an exposition. The large questions of policy, except as already mentioned, are outside its scope. It will, however, present and attempt to analyze the provisions of the Uniform Partnership Act, compare and contrast them with those of our codes, and particularly show wherein existing law would be changed. This is done in the hope that those who read may judge for themselves whether the change is so great as to warrant

8 See Samuel Williston, The Uniform Partnership Act, with some Remarks on other Uniform Commercial Laws, 63 University of Pennsylvania Law Review, 196.

${ }^{9}$ Sales Act: see Lauriz Vold, Some Reasons Why the Code States Should Adopt the Uniform Sales Act, 5 California Law Review, 400, 471; 6 id. 37; Max Radin, The Law of Sales in California and the Uniform Sales Act, 9 California Law Review, 27. Negotiable Instruments Act: Maurice E. Harrison, The Adoption of the Negotiable Instruments Law in California, 6 California Law Review, 23. The Stock Transfer Act will be discussed in an early issue. 
committing ourselves to a policy of non-uniformity in order to retain our law in statu quo.

\section{The Theory of the Uniform Partnership Act.}

One of the questions much discussed by the commissioners in determining which of the many drafts considered was to be finally recommended was what underlying conception as to the nature of a partnership should be favored. The earliest proposal, prepared at the request of the commissioners by the late Dean Ames of the Harvard Law School, was frankly based on the theory that the partnership should be looked upon as a legal entity having a legal personality apart from that of its members. ${ }^{10}$ This theory was ultimately discarded, and there are those who think that in so doing the commissioners made a mistake. ${ }^{11}$ Because it was believed that in the great majority of states the so-called aggregate theory as opposed to the entity theory was really law, the commissioners ultimately recommended a draft based on the former conception..$^{12}$ As will appear, there are certain features of the Uniform Partnership Act that can be explained only on the theory that the partnership is an entity, but because this is equally true of the partnership law of this state, and because in general California looks on a partnership as an aggregate of individuals and not as an entity, ${ }^{13}$ it is evident that in the underlying concep-

$10 \mathrm{Wm}$. Draper Lewis, Desirability of Expressing the Law of Partnership in Statutory Form, 60 University of Pennsylvania Law Review, 93; The Uniform Partnership Act, 24 Yale Law Journal, 617; The Uniform Partnership Act-New York's Failure to Adopt it, 18 Columbia Law Review, 582; I. B. Lichtenberger, The Uniform Partnership Act, 63 University of Pennsylvania Law Review, 639; see also page 5 of the Commissioners' Report on the Act, referred to in paragraph $\mathrm{V}$ of this article; Reports of American Bar Association, 1903, p. 501; 1908, pp. 983, 1048; 1909 , p. 1081. For discussion of Act in relation to Wisconsin law, see 1 Wisconsin Law Review, 5; to West Virginia law, see 27 West Virginia Law Quarterly, 28; to New York law, see 18 Columbia Law Review, 582.

${ }_{11}$ Judson A. Crane, The Uniform Partnership Act-A Criticism, 28 Harvard Law Review, 762. See also in this connection, Wm. Draper Lewis, A Reply to Mr. Crane's Criticism, 29 Harvard Law Review, 158, 291 ; Judson A. Crane, The Uniform Partnership Act and Legal Persons, 29 Harvard Law Review, 838; Scott Rowley, The Development of Partnership Law, 24 Case \& Comment, 367. For an historical consideration of the partnership as an entity, see Joseph H. Drake, Partnership Entity and Tenancy in Partnership; The Struggle for a Definition, 15 Michigan Law Review, 609; Francis M. Burdick, Some Judicial Myths, 22 Harvard Law Review. 393, 396.

${ }_{12}$ See articles cited in note 10 . It is interesting to notice that in phraseology, at least, the partnership is frequently considered as a unit. 28 Harvard Law. Review, 769.

${ }_{13}$ But see Gleason v. White (1867) $34 \mathrm{Cal}$. 258, and Asbestos Manufacturing efr. Co. v. Lenning-Rapple Eng. Co. (1914) 26 Cal. App. 177, 146 Pac. 188. 
tion no change would be worked in our law by allying ourselves with other states which have adopted the uniform act.

There is no place here for a discussion of the relative merits of the two theories. The entity theory has much to commend it from the scientific and mercantile point of view and also in the creation of a larger uniformity of conception throughout the world, but its adoption would certainly require a great many more readjustments in the United States than would the aggregate theory.

\section{Novel Features of Uniform Partnership Act.}

The commissioners have published an annotated text of the Act in which there is a bibliography of articles on the subject, and a discussion of each section with the reasons for its inclusion. .t $^{14}$ This text is of great use to any one desiring to study the act in its general aspects. One text-book on the law of partnership also considers that law in connection with the Act. ${ }^{15}$

In several matters the Act works a complete change in the usual rules as to partnership. These will only be indicated here, leaving a fuller treatment for later paragraphs. (1) The Act creates a form of ownership called tenancy in partnership. ${ }^{16}$ In short, it recognizes that the present law as to joint tenancy and tenancy in common, existing in more or less crystallized form before partnership law grew up, is not appropriate, even as modified in equity, to the partnership relation. That the creation of this new form of ownership is not so radical in California as it seems will appear later. ${ }^{17}$ (2) The Act renders impossible attachment of specific firm property by an individual creditor of one partner, and, instead, gives that creditor a right to obtain a charging order against the firm. ${ }^{18}$ This is the adoption of an English method of collecting such debts, and is, of couse, like a combination of the legal garnishment with the equitable bill to reach and apply a debtor's assets. (3) The Act permits real estate to be taken and conveyed in the firm name, recognizing that to this extent, if no further, the firm

${ }_{14}$ See references in notes 10,11, and also 1 American Bar Association Journal (1915), 398; 72 Legal Intelligencer, 1915; 80 Central Law Journal, 435; 3 American Bar Association Journal (1917), 529; 66 University of Pennsylvania Law Review, 310 .

15 F. M. Burdick, The Law of Partnership (3d ed.), Boston; Little, Brown and Co., 1917 .

${ }_{16}$ See Drake, 15 Michigan Law Review, 609, for an historical consideration of this doctrine.

${ }^{17} \S 28$. See par. XXXIII, to appear.

18 See par. XXXVI, to appear. 
is a legal entity. ${ }^{19}$ (4) Firm property remains liable to firm debts although new blood is let in. ${ }^{20}$

IV. Place of Uniform Partnership Act in Our Code System. There is another problem the nature and difficulty of which should be indicated before the sections of the Act are considered seriatim. How can a uniform act be made to fit into our complicated system of codes? Our law on the subject is not expressed in the Civil Code alone, and a repeal of sections 2395 to 2472 of that Code inclusive will leave a number of other sections relating to partnerships still on the face of the statute books and still law. To instance a few of these: unless the Uniform Limited Partnership Act is simultaneously adopted, Civil Code sections 2477 to 2510, relating to special partnerships, and certainly Civil Code sections 2511-2520 relating to mining partnerships should stand.

There are a number of sections in the Code of Civil Procedure bearing on partnership matters. Certain of these, particularly sections 388 and 414, are clearly not in conflict with the Uniform Act and can properly be let alone if the latter is passed. The same is true of certain sections of the Penal Code, the Political Code, and of the General Laws. There are, however, several sections of the Code of Civil Procedure as to which a certain chance of conflict arises. The controlling force of one set or the other should at least be declared when the act is passed. These possible conflicts will be discussed in later paragraphs; and at the end of this article the legislative changes necessitated by the adoption of the Uniform Partnership Act will be listed. ${ }^{21}$

\section{Method of Comparing California Law With That of UNIFORM ACT.}

Having disposed of these preliminary questions we reach the uniform Act itself. The method adopted is, to set forth the text of the Act, to list parallel references to our codes, and to discuss the provision itself generally, and to consider it in the light of existing California law.

It has seemed desirable to the author to suppress his inclination to read into the Act what he thinks the intelligent men versed in partnership law who drafted it intended to be there. He has endeavored to preserve the point of view of a judge or lawyer in the hurry of trial or opinion-giving, when there is no time to read the Act as a whole and all the literature upon it. Often he has

19 See par. XVI.

20 See pars. XXIII and LI, to appear.

21 See par. LV, to appear. 
stated doubts and questions that will occur and arguments that would naturally be made at such a time, rather than the view finally to be taken if we had time enough to reach the perfect solution. This has resulted in criticisms that may, if deeply considered, seem unfounded. The author, however, believes that this point of view is the only proper one, for it looks upon the Act as it will be looked upon in actual practice. For more synthetic consideration of the Act, the reader is referred to the articles cited in the notes to paragraph II.

Hereafter the Uniform Partnership Act will be referred to as "U. P. A.", and the Civil Code as "C. C." The text of the former used in this discussion is that contained in a pamphlet entitled "Uniform Partnership Act Drafted by the National Conference of Commissioners on Uniform States Laws and by it Approved and Recommended for Enactment in all the States at its Conference at Washington, D. C., October 14, 1914, Edition of 1920."22

\section{NAME of Act.}

U. P. A. Section 1. This act may be cited as Uniform Partnership Act.

Parallel references: none.

While it is perhaps somewhat opposed to the practice of the Civil Code to entitle any given set of sections "an act", nevertheless this difficulty can be met, ${ }^{23}$ and furthermore the grouping of certain sections on one subject is, of course, desirable.

\section{Definition of Terms.}

U. P. A. Section 2. In this act, "Court" includes every court and judge having jurisdiction in the case.

"Business" includes every trade, occupation, or profession.

"Person" includes individuals, partnerships, corporations, and other associations.

"Bankrupt" includes bankrupt under the Federal Bankruptcy Act or insolvent under any state insolvent act.

"Conveyance" includes every assignment, lease, mortgage, or encumbrance. land.

"Real property" includes land and any interest or estate in

Parallel references: none.

This is, of course, now the common practice in new legislation. ${ }^{24}$

22 Other texts of the act are to be found in Burdick, Partnership (3d ed.), Appx. B, p. 427; Terry, Uniform State Laws, 414; and, of course, in the laws of the states adopting the act. See n. 2 .

${ }_{23}$ Section 1 can be omitted, or the words "this act" changed to read, "Title X, chapters I and II."

24 E. g. Cal. Civ. Code, $\S 2132$ b; Cal. Stats. 1917, p. 831, § 3. 
In connection with the definitions, they do not extend partnerships to organizations not previously held to be such, as will appear in the discussion of section 6 hereafter. Nor does the definition of "business" as including every trade, occupation, or profession extend partnerships to activities not previously included, as will also appear.

\section{InTERPRETATION of "KNowledge" and "Notice" as Used IN THE ACT.}

U.P.A. Section 3. (1) A person has "knowledge" of a fact within the meaning of this act not only when he has actual knowledge thereof, but also when he has knowledge of such other facts as in the circumstances shows bad faith.

(2) A person has "notice" of a fact within the meaning of this act when the person who claims the benefit of the notice

(a) States the fact to such person, or

(b) Delivers through the mail, or by other means of communication, a written statement of the fact to such person or to a proper person at his place of business or residence.

Parallel references: compare C. C. $\$ \S 2417,2453,2454$, 2509.

As the commissioners point out, the terms "notice" and "knowledge" are frequently used one for the other with resulting confusion. The purpose of section 3 is to avoid that confusion, and particuiarly to make it clear how far a statement sent by mail is "notice". It will be observed that delivery is required, but that there may be notice when the statement is delivered at the place of business or residence of the person concerned. The word "written" will not be interpreted as excluding printed or typewritten communications. ${ }^{25}$ The commissioners state that the insertion of the word "printed" would raise a doubt whether the delivery of a newspaper containing somewhere the facts, notice of which is to be given, was "notice" within the section, and that the use of the words "written statement of the fact to such person" makes it clear that in such case there would not be notice. It does not seem to the writer that this conclusion is any too certain, but however that may be the California law would not be changed for the worse. The term "notice" is once used in the Civil Code (section 2417, notice of renunciation of future profits) without any definition at all of what "notice" is. In another connection 
(section 2453, notice of termination) the term "personal notice" is used, with the possible result that notice through an agent is insufficient-as it certainly should not be. In fact, U. P. A., by providing that the law of agency shall apply under the act (section 4, subdiv. 3), clarifies, for it makes C. C. section 2332 operative as it otherwise might not be. The rest of section 2453, making newspaper publication of the fact of a dissolution sufficient as to persons who have not previously had dealings with the partnership, is not affected by U.P.A. section 3 as appears from U.P. A. section 35 (1) (b) (II), which is practically identical with the latter portion of section 2453.

The provisions of the U. P. A. as to notice do, however, seem to change the law in another respect. By C. C. section 2533 a change in partnership name plainly revealing the withdrawal of a partner is notice of such fact if communiacted. Such a change would scarcely seem to be a statement of the fact of withdrawal under U. P. A. section 3 (2).

\section{Rules of Constructron}

U. P. A. Sectron 4. (1) The rule that statutes in derogation of the common law are to be strictly construed shall have no application to this act.

(2) The law of estoppel shall apply under this act.

(3) The law of agency shall apply under this act.

(4) This act shall be so interpreted and construed as to effect its general purpose to make uniform the law of those states which enact it.

(5) This act shall not be construed so as to impair the obligations of any contract existing when the act goes into effect, nor to affect any action or proceedings begun or right accrued before this act takes effect.

Parallel references:

to subsections (1) and (5), C. C., $\$ \$ 4,6$.

to subsection (2), C. C. P., § 1962, Cf. C. C., § 2444.

to subsection (3), C.C., \& 2443.

Civil Code section 4 renders unnecessary U. P. A. section 4 (1), but the repetition of the principle certainly does no harm. It is, of course, statutory law in this state, and certainly the same rule of construction should apply to substituted sections in the Code as applies to the rest of the Code and that formerly applied to the sections which are replaced.

The provision that the law of estoppel shall apply leaves effective the general rules of estoppel expressed in Code of Civil Pro- 
cedure section 1962.86 While there are particular provisions as to estoppels of one held out as partner in the sections of the Civil Code relating to partnership (sections 2444, 2431), these sections have their counterpart in U. P. A. section 16, and therefore the adoption of the latter act will not leave persons asserting such estoppels with nothing else to rely upon but the general provision of the Code of Civil Procedure.

The provisions of U. P. A. section 4 (3) have already been mentioned. Of course, the principles relating to the liability of one partner for the acts of another are largely an outgrowth of the law of agency for the reason that when partnership litigation first came before the courts it had to be decided according to existing precedents that did not take into account at all the peculiarities of the partnership relation. There have, however, grown up certain definite and crystallized rules. Many of these have been incorporated in the Civil Code (sections 2429, 2430, 2431). But the repeal of the Civil Code will not throw at large again all the various provisions, for the U. P. A., like the Civil Code, defines the authority of one partner to bind his fellows. A comparison between the two acts will later be made. ${ }^{27}$

U. P. A. section 4 (4) prescribes a canon of construction contained in all the Uniform Acts. Our legislature has already given effect to the principle in another connection. ${ }^{28}$ Section 4 (5) requires no comment, being very similar to that in C. C. section 6.

\section{Rules for Cases Not Provided for in U. P. A.}

U. P. A. Section. 5. In any case not provided for in this act the rules of law and equity, including the law merchant, shall govern.

Parallel references: none.

The only phrase in this section that requires comment is perhaps "including the law merchant." It is a commonplace that much of the present partnership law is traceable to the customs of merchants. ${ }^{29}$ So long as merchants do business they will have their customs, with reference to which commercial agreements must be interpreted. The customs of merchants are peculiarly apt

26 Therefore no different result would be reached in a case like Willey v. Crocker-Woolworth National Bank (1904) 141 Cal. 508, 75 Pac. 106.

27 See par. XV.

${ }_{28}$ Cal. Civ. Code, § 2132a.

20 Burdick, Partnership (3d. ed.) 2, and see Burdick, What is a Law Merchant? Select Essays in Anglo-American Law, vol. III, p. 45 . Cf. Cal. Civ. Code, \$ 3266d. 
in connection with partnership questions. Their existence as determining the scope of an agreement has often been recognized. ${ }^{80}$ While there is no longer a law merchant as an independent legal system enforceable in its special courts as to particular persons and matters, there does still exist a law merchant in the large sense of a body of mercantile rules and customs, from which the common law is, so to speak, constantly refreshed and amplified. Recognition in statute form of the fact that a court may look to these rules and customs is but explicit recognition of what has long been done without a statute.

\section{Partnership Defined.}

U. P. A. Section 6. (1) A partnership is an association of two or more persons to carry on as co-owners a business for profit.

(2) But any association formed under any other statute of this state, or any statutes adopted by authority, other than the authority of this state, is not a partnership under this act, unless such association would have been a partnership in this state prior to the adoption of this act; but this act shall apply to limited partnerships except in so far as the statutes relating to such partnerships are inconsistent herewith.

Parallel references: C. C. $\S \S 2395,2397$.

(1) The difference between these definitions is not great. The fundamental word in both is the same, that is, the general word "association", into which the courts can put whatever idea they choose. The commissioners say that this word necessarily connotes the idea of a voluntary "association". That a partnership must be voluntary, that is, intended in fact if not in name, is undoubtedly law in California ${ }^{31}$ and will seemingly renain law if the U. P. A. is adopted, even though unexpressed as it now is in C. C. section 2397. The Code definition uses the phrase "for the purpose of carrying on", whereas U. P. A. says "to carry on". There seems to be no great difference in idea. Both phrases seem to convey the idea of futurity, which is not usually the law. ${ }^{32}$ The commissioners declare that their phraseology makes it possible for a court to wind up as a partnership under U. P. A. sections 29-43, the relationship resulting when two partners make their contribution as agreed but one refuses to carry on the business. The question

so Bank of Buffalo v. Thompson (1890) 121 N. Y. 280, 24 N. E. 473.

31 Burdick, Partnership (3d. ed:) 5.

$\$ 2$ Burdick, p. 17. 
is still open in California..38 It would seem that the phrase "for the purpose of carrying on" permits this course of action no more and no less than the phrase "to carry on".

The words "as co-owners" in the U. P. A. definition, do, however, incorporate an idea not fully expressed in the Code. ${ }^{3 *}$ This phrase, according to the commissioners, distinguishes a partnership from an agency. In California inere agency arrangements, even where the agent receives a share of the profits, have never been held to result in partnerships. ${ }^{35}$ The idea of partnership as to third persons but not inter se has never received judicial recognition here, ${ }^{36}$ and is repudiated by C. C. sections 2444,2445 . It is not law, of course, under U. P. A. sections 7, 16. The phrase in question only makes certain what is already law. Undoubtedly the idea here expressed carries out the idea made clear in the leading case of Cox v. Hickman, ${ }^{37}$ and there is a gain in clarity over the corresponding vague word "together" in the Code. ${ }^{88}$

The last difference between U. P. A. and Code is with reference to the purpose of profit-making. The former declares this purpose to be "to carry on .... a business for profit"; and the latter of "dividing the profit between them." It will be noticed that apparently under the U. P. A. there might be a partnership although all the profit went to one partner, provided the purpose of both partners was to make a profit. This is perhaps not the usual rule, but the cases where this question would occur would necessarily be rare, and in any event the term might be construed as implying mutual profit. On the other hand, the phrase used in the Code emphasizes the division of profits unduly,

ss Cf., however, Powell v. Maguire (1872) 43 Cal. 11; Taylor v. Nelson (1915) 26 Cal. App. 681, 147 Pac. 1189, intimating that there may not be an equitable winding up.

34 Possibly in cases where there is great concentration of power and benefits in one party, a stronger argument could be made as to the nonexistence of a partnership under U. P. A. $\$ \S 6,7$, than under C. C. $\$ 2395$, these facts tending to show that the parties are not co-owners; as, for example, Donleavey v. Johnston (1914) $24 \mathrm{Cal}$. App. 319, 141 Pac. 229.

${ }_{35}$ Barber v. Cazalis (1866) $30 \mathrm{Cal}$.92; Lyden v. Spohn-Patrick Co. (1909) 155 Cal. 177, 100 Pac. 236; Wheeler v. Farmer (1869) 38 Cal. 203; Stone v. Bancroft (1896) 112 Cal. 652, 44 Pac. 1069.

${ }_{38}$ Loans, principal or interest payable out of profits: Cadenasso v. Antonelle (1899) $127 \mathrm{Cal}$. 382, 59 Pac. 765; Lyden v. Spohn-Patrick Co. (1909) 155 Cal. 177, 100 Pac. 236; Martin v. Skarp \& Fellows Cons. Co. (1917) 34 Cal. App. 584, 168 Pac. 373. But cf. Westcott v. Gilman (1915) 170 Cal. 562, 150 Pac. 777, Ann. Cas. 1916E 437; Bowas v. Pioneer Tow Line (Dist. Cal. 1871) 2 Sawy. 21, 3 Fed. Cas. No. 1713.

37 (1860) 8 H. L. Cas. 268.

3s For a case giving to this phrase in C. C. $\$ 2395$ a literal meaning very nearly that of U. P. A. \$ 6, see Martin v. Skarp \& Fellows Cons. Co. (1917) 34 Cal. App. 584, 168 Pac. 373. 
for it might exclude an arrangement whereby profits were not divided but reinvested.

(2) Of the second subsection the commissioners say: "The paragraph as drawn makes any association formed under a statute a partnership if it would have been a partnership in the state if the act had not been adopted. If the association would not have been a partnership had the act not been adopted, the adoption of the act does not make it a partnership." In other words, as to associations formed under other sections of the Code before the Uniform Act is adopted, their status will not be changed, and apparently as to those formed afterwards the question must be decided in the light of those sections taken in connection with U. P. A. section 6 (1), but this is none too clear. It would seem that a different result can be reached only as to a given group, if the statute under which it organized leaves the point open and if U. P. A. section $6(1)$ is looked upon as laying down a different test from C. C. section 2395. This is unlikely except in a few unusual situations, as has already been noted.

The last clause of the subsection should not, however, be left as it is, unless the Limited Partnership Act is contemporaneously adopted, because under the Code there are no "limited" partnerships. But special partnerships can be created in this state, and the phrase should be made applicable to them, and also to mining partnerships.

Neither U. P. A. section 6 nor C. C. section 2395 verbally require as a requisite to the existence of a partnership a lawful business. Comment will be made on this point in a later connection. ${ }^{39}$

In a note are given a number of California decisions on the borderline but holding that a partnership existed. It is difficult to see how any one of them would have to be decided differently under the U. P. A.40

39 See par. XXX, to appear.

40 Buying and selling real estate: Arnold v. Loomis (1915) 170 Cal. 95, 148 Pac. 518; Chapman v. Hughes (1894) 104 Cal. 302, 37. Pac. 1048; Llewellyn v. Levi (1909) $157 \mathrm{Cal}$. 31, 106 Pac. 219; hotel business: Irvine \& Muir Lumber Co. v. Holmes (1915) 26 Cal. App. 453, 147 Pac. 229; buying and selling fruit; Westcott v. Gilman (1915) $170 \mathrm{Cal} .562$, $150 \mathrm{Pac}$. 777, Ann. Cas. 1916E 437; selling lumber to a sawmill: Chapin v. Brown (1894) 101 Cal. 500, 35 Pac. 1051 semble; growing oranges: Los Angeles Bank v. Wallace (1894) $101 \mathrm{Cal}$. 478, $36 \mathrm{Pac}$. 197 semble; barge and tug working together in carrying goods; Bowas v. Pioneer Tow Line (Dist. Cal. 1871) 2 Sawy. 21, 3 Fed Cas. No. 1713; oil, mineral or land exploitation: Callahan v. Danziger (1916) 32 Cal. App. 405, 163 . Pac. 65 ; Carpenter v. Hathaway (1891) 87 Cal. 434, 25 Pac. 549; Harris v. Hillegass (1880) 54 Cal. 463; labor union: Gorman v. Russell (1860) 14 Cal. 531; 
XII. Rules for Determining the Existence of a Partnership U. P. A. Section 7. In determining whether a partnership exists, these rules shall apply:

(1) Except as provided by section 16 persons who are not partners as to each other are not partners as to third persons.

(2) Joint tenancy, tenancy in common, tenancy by the entireties, joint property, common property, or part ownership does not of itself establish a partnership, whether such co-owners do or do not share any profits made by the use of the property.

(3) The sharing of gross returns does not of itself establish a partnership, whether or not the persons sharing. them have a joint or common right or interest in any property from which the returns are derived.

(4) The receipt by a person of a share of the profits of a busmess is prima facie evidence that he is a partner in the business, but no such inference shall be drawn if such profits were received in payment:

(a) As a debt by installments or otherwise,

(b) As wages of an employee or rent to a landlord,

(c) As an annuity to a widow or representative of a deceased partner,

(d) As interest on a loan, though the amount of payment vary with the profits of the business.

(e) As the consideration for the sale of a good-will of a business or other property by installments or otherwise.

Parallel references: (1) Cf. C. C. $\$ \$ 2445,2444,2396$.

This section is in amplification of the definition in U. P. A. section 6 (1). It has no counterpart in the Code except as will be noted, but the rules here made statutory have in large part received judicial sanction in California. This will appear from an examination of the cases cited in the note. ${ }^{11}$

It has already been observed that the bastard partnership as to third persons is by subsection (1) impossible. No change is made

contribution of capital by one and labor by other; Lampher v. Warshauer (1915) $28 \mathrm{Cal}$. App. 457, 152 Pac. 933; mining partnership: Settembre v. Putnam (1866) 30 Cal. 490.

41 U. P. A. \$ 7. (1) See note 36. (2) Cf. Quackenbush v. Sawyer (1880) 54 Cal. 439 ; William v. Tam (1900) 131 Cal. 64, 63 Pac. i33. (3) Wheeler v. Farmer (1869) 38 Cal. 203; Quackenbush v. Sawyer (1880) 54 Cal. 439; Smith v. Schultz (1891) 89 Cal. 526, 26 Pac. 1089; cf. Phillips v. Mires (1905) 2 Cal. App. 274, 83 Pac. 300. (4) (a) See note 47. (b) Nofsinger v. Goldman (1898) 122 Cal. 609, 55 Pac. 425; Smith v. Schultz, supra; Vanderhurst v. De Witt (1892) 95 Cal. 57, 30 Pac. 94, 20 L. R. A. 595. (c) Cf. Noonan v. Nunan (1888) 76 Cal. 44, 18 Pac. 98. (d) See note 36. Joint laborers fulfilling a contract are not necessarily partners. Smith v. Moynihan (1872) 44 Cal. 53; nor persons jointly staking mining claims, Prince v. Lamb. (1900) 128 Cal. 120, 60 Pac. 689. 
in our law in this respect. ${ }^{22}$ C. C. section 2445 is identical in purpose with subsection (1).

It would seem that the phrase "common property" in subsection (2) would be sufficient in California to prevent any argument that the community was prima facie evidence of a partnership. ${ }^{43}$

A question arises whether the necessary omission of C. C. section $2396^{43}$ would work a change in the law. It is submitted that no such change would result, in view of the words "part ownership" in subsection (2) and of the other subsections of this section.

Possible confusion might arise in the interpretation of clause (b) of subsection 4. The words "rent" and "landlord" here used suggest that only the rent of real estate is intended. The rule ought to apply where it is "rent" of personal property, as the hire of a machine. There are cases in California in effect holding that the receipt of profits in payment of the hire of a threshing machine is not prima facie evidence of a partnership. ${ }^{45}$ Would not this rule be slightly shaken if the U. P. A. were adopted?

There are numerous cases in California determining how the existence of a partnership may be proved, and like questions. The rules they lay down have in large part come about judicially and are not dependent on the Code. The slight change in U. P. A. section 6 defining a partnership will not alter these rules. Nor will the section under discussion (U. P. A. section 7) affect them merely because a case turns on a different set of facts. Mr. Justice Henshaw's analysis of the nature of the inquiry to be made when there is a suit between partners and that to be made when a third person is suing the firm will remain as enlightening now as it ever was. ${ }^{46}$ In a note are listed some California cases passing upon the sufficiency of the evidence of a partnership. It would seem that all of them would be decided in the same way under the U. P. A. ${ }^{.7}$

\footnotetext{
42 See note 36.

43 See Lynam v. Vorwerk (1910) 13 Cal. App. 507, 110 Pac. 355.

44 Cases have been decided in reliance upon this subsection. Hendy v. March (1888) 75 Cal. 566, 17 Pac. 702.

45 Nofsinger v. Goldman (1898) 122 Cal. 609, 55 Pac. 425; Vanderhurst v. DeWitt (1892) 95 Cal. 57, 30 Pac. 94,20 L. R. A. 595.

46 Westcott v. Gilman (1915) 170 Cal. 562, 150 Pac. 777, Ann. Cas. $1916 \mathrm{E} 437$.

47 Sinclair v. Wood (1853) 3 Cal. 98, holding that general reputation is not admissible to show a partnership, except to corroborate other testimony; Turner v. Mellhaney (1857) 8 Cal. 575 and Hudson v. Simon (1856) 6 Cal. 453 , that unauthorized statement of third party cannot be used to prove partnership; Bryce v. Joynt (1883) 63 Cal. 375, 49 Am. Rep. 94, that joint books of a number of men cannot be used in the first instance to prove a partnership but only to corroborate other evidence to that effect; Hammond v. Borgwardt (1899) $126 \mathrm{Cal}$. 611, $59 \mathrm{Pac}$. 121, that a statement by a party that he is a partner is not sufficient, but see Chapin v. Brown
} 
A problem upon which U. P. A. section 7 might well have given some workable rule is that arising when there is a defective corporation. To provide that "a partnership . . . . is not necessarily the result of an abortive attempt to organize a corporation" would not seem to extend the U. P. A. where it ought not to go. This has been said in California but in a case arising before the Civil Code went into effect. ${ }^{48}$.

U. P. A. sections 6 and 7 do not pass on the power of a corporation to be a partner, and quite rightly, for this is a question of corporation law. ${ }^{49}$ Nor do these sections prescribe that there must be a written agreement. ${ }^{\text {so }}$

\section{Partnership Property.}

U. P. A. Section 8. (1) All property originally brought into the partnership stock or subsequently acquired by purchase or otherwise, on account of the partnership, is partnership property.

(2) Unless the contrary intention appears, property acquired with partnership funds is partnership property.

(3) Any estate in real property may be acquired in the partnership name. Title so acquired can be conveyed only in the partnership name.

(4) A conveyance to a partnership in the partnership name, though without words of inleritance, passes the entire estate of the grantor unless a contrary intent appears.

Parallel references: C. C. $\$ \S 2401,2406$.

Subsection (1) is the same as C. C. section 2401 with only minor differences in wording and greater explicitness.

(1894) 101 Cal. 500, 35 Pac. 1051; Robarts v. Haley (1884) 65 Cal. 397, 4 Pac. 385, that signing an agreement as parties of first part does not show partnership; Niroad v. Farnell (1909) 11 Cal. App. 767, 106 Pac. 252, that a partnership may be proved without showing an express agreement to be partners; Lynam v. Vorwerk (1910) 13 Cal. App. 507, 110 Pac. 355, that the deposit of money in the names of two persons is not prima facie evidence of a partnership; Mortimer v. Marder (1892) 93 Cal. 172, 28 Pac. 814, that a certificate of partnership is prima facie evidence that a partnership exists.

48 Blanchard v. Kaull (1872) 44 Cal. 440, 1 Cal. Unrep. Cas. 665.

40 Cf. Bates v. Coronado Beach Co. (1895) 109 Cal. 160, 41 Pac. 855; Cuyamaca Granite Co. v. Pacific Paving Co. (1892) 95 Cal. 252, 30 Pac. 525; Willey v. Crocker-Woolworth National Bank (1904) 141 Cal. 508, 75 Pac. 106; Yancy v. Morton (1892) 94 Cal. 558, 29 Pac. 1111.

${ }^{50}$ Such an agreement is not required, Scott \& Scott v. Jungquist (1918) 179 Cal. 7, 175 Pac. 412; cf. Young v. Pearson (1851) 1 Cal. 448; Doudell v. Shoo (1912) 20 Cal. App. 424, 129 Pac. 478. The leading case, holding that there may be an oral partnership to deal in real estate and that it can be wound up in the usual way even though title does not stand in the name of all the partners and even though all the land has not been sold, would still be law: Bates v. Babcock (1892) 95 Cal. 479,30 Pac. 605, 29 Am. St. Rep. 133, 16 L. R. A. 745; see also Koyer v. Willmon (1907) 150 Cal. 785, 90 Pac. 135; but see Gray v. Palmer (1858) 9 Cal. 616. 
Subsection (2) is identical in intent with C. C. section 2406.

With regard to subsections ( 3 ) and (4), however, a real change would be wrought in California law. This will be discussed in connection with U. P. A. section 10 (paragraph XVI).

XIV. Relations of Partners to Persons Dealing With the PARTNERSHIP

With regard to this topic, it should be noted that herein is included not only those topics which have their equivalent in Article IV of Title X of the Civil Code (C. C. sections 2442 to 2445) relating to liability of partners, but in Article II (C. C. sections 2428 to 2431 ) relating to powers of partners.

XV. Partner Agent of Partnership as to Partnersitp BusINESS.

U.P.A. Section 9. (1) Every partner is an agent of the partnership for the purpose of its business, and the act of every partner, including the execution in the partnership name of any instrument, for apparently carrying on in the usual way the business of the partnership of which he is a member binds the partnership, unless the partner so acting has in fact no authority to act for the partnership in the particular matter, and the person with whom he is dealing has knowledge of the fact that he has no such authority.

(2) An act of a partner which is not apparently for the carrying on of the business of the partnership in the usual way does not bind the partnership unless authorized by the other partners.

(3) Unless authorized by the other partners or unless they have abandoned the business, one or more but less than all the partners have no authority to:

(a) Assign the partnership property in trust for creditors or on the assignee's promise to pay the debts of the partnership.

(b) Dispose of the good-will of the business,

(c) Do any other act which would make it impossible to carry on the ordinary business of a partnership,

(d) Confess a judgment,

(e) Submit a partnership claim or liability to arbitration or reference.

(4) No act of a partner in contravention of a restriction on authority shall bind the partnership to persons having knowledge of the restriction.

Parallel references: C. C. $\$ \$ 2429,2430,2431$.

(1) The similarity between U: P. A. section 9 and C. C. sections $242 y$ and 2430 , is so great as to suggest that the latter or its 
parents were the model for the former. There is, however, one difference between the provisions of subsection (1) and its correspondent, C. C. section 2429. The latter speaks in terms of "authority" and declares that every partner has "authority" to do whatever is necessary to carry on business in the ordinary manner. Let us suppose that a partner does an act which is opposed to a private arrangement between the partners, but is the sort of act which in most partnerships would be looked upon as necessary to carry on business in the ordinary manner. Does such an act bind the partnership? It would seem not, under C. C. section 2429, if the word "authority" is to be given its normal effect. In short, does the section state a presumption or an irrevocable rule of law? If it states the former, then apparently the third person could hold the partnership only by establishing a strict estoppel. If it states the latter, then the third person could hold the partnership even if he had knowledge of the private arrangement, which seems scarcely fair. These questions are not satisfactorily answered by decided cases..$^{51}$ In any event, this section of the Code taken in connection with other sections does not seem to make it possible to take that midde view which is more and more popular in connection with questions of agency such as that here involved. This middle view is roughly this: the partner who does an act usually done by partners carrying on business in the usual way binds the partnership thereby, unless the third party actually knew of the private arrangement, the burden of proving such knowledge apparently being on the persons seeking to make out the defense. In other words, the doctrine of estoppel is not strictly applied; a power in the partner to bind the firm notwithstanding secret arrangements is recognized; and, instead of requiring the

51 Illustrative California cases where the firm was held liable: promissory notes made by one partner in firm name but for private purposes, Rich v. Davis (1856) $6 \mathrm{Cal}$. 141; promissory notes of mining partnership for firm purpose, Decker v. Howell (1872) 42 Cal. 363; same, a store, Rich v. Davis (1856) 6 Cal. 163; borrowing on note for firm purpose, Krasky v. Wollpert (1901) $134 \mathrm{Cal}$. 338, 66 Pac. 309, an interesting case because note was signed only in name of active partner, which name, however, was name under which firm did business; assignment of note taken as security for firm credit, Tusch v. Cummings (1873) 1 Cal. Unrep. Cas. 782; pledge of a firm's order for money for a private debt with a bank which knew that there was a partnership, and that transaction might redound to detriment of other partner, Breeze v. International Banking Corp. (1914) 25 Cal. App. 437, 143 Pac. 1066; loan to buy merchandise, Dammon v. Beecher (1893) $97 \mathrm{Cal}$. 530, $32 \mathrm{Pac}$. 573; note given to make good loss of property left with partnership, Pierce v. Jackson (1863) 21 Cal. 636. Where the firm was not held liable; mortgage of crop, cf. In re Bregard (1890) 84 Ca1. 322, 24 Pac. 317, assignment of a water right, Henderson v. Nicholas (1885) 67 Cal. 152, 7 Pac. 412; indorsement apparent as accommodation on face of note, Hendrie v. Berkowitz (1869) 37 Cal. 113, 99 Am. Dec. 251. 
third party to prove affirmatively a representation and his reliance thereon, he is required merely to show an act in the ordinary course of business, and his right of action is defeated only by proof that he was not, so to speak, empty-minded, but that he actually knew of the secret arrangement.

Subsection (1) recognizes this middle view to be the law, although its phraseology might be clearer. The words for "apparently carrying on" are unfortunate, because the object of the word "apparent" is not expressed. To whom must the act be apparent as an act in the usual way? If it must be apparent to the third person there is added a new fact to his burden of proofthe element of personal reliance on the appearance of things. If the act as done must carry to the court or jury as judges of fact the appearance of an act in the usual way, then the rule laid down by the subsection will perhaps be easier of application. The test will come when, let us say, a Patagonian arrives without knowledge of the partnership and makes a contract without inquiry. ${ }^{52}$

Again, ought the partnership always to be bound by an act with the glittering appearance of an act in the usual course, although not in fact in such course either of the partnership involved or of any partnership? The sale by a single partner for a small sum of a secret process of manufacture upon which the whole business of the firm depends would not be in the usual way, yet it might have that appearance both to the world and to the third person. Such a sale, outside a partner's authority, should not bind the firm. Should not the test be, not the appearance of things, but rather the nature of the act; is it the sort of thing usually authorized by similar partnerships ?53 Protection of the third party can go too far; the strict rules of estoppel can be too much cut down; and vicarious liability carried to absurd lengths.

But though the ambiguity is to be regretted, the subsection is less ambiguous than. C. C. section 2429, and tends to establish a more modern doctrine.

(2) Subsection (2) has its counterpart in C. C. section $2430(7)$.

(3) Subsection (3) would seem to be based largely on C. C. section 2430. There are a few differences. The latter declares that a partner has no authority to do the various acts specified, apparently in any case, except where the business has been wholly

52 In the controversy between Mr. Crane and Mr. Lewis this possible interpretation was not touched on; 28 Harvard Law Review, 779, 29 id. 299.

${ }^{53}$ See Mr. Crane, 28 Harvard Law Review, 779. 
abandoned to him. Strictly, perhaps, two partners out of four or more might do these things. It would seem clear, however, that except as will be noted in considering U. P. A. section 18, more than one and less than all would have no greater powers in these connections than one. This is made clear by U. P. A. section 9 (3).

Both C. C. section 2430 and U. P. A. section 9 (3) enlarge the rights of a partner when other partners have abandoned the business. Of course, in such event, the remaining partner stands in a difficult position, for he can not appropriate his absent partner's share, but is exposed to a greater degree of liability by reason of the latter's absence. He should certainly have some if not all of the rights of a survivor. Neither the Civil Code nor the U. P. A. say to what extent his authority is enlarged. Seemingly he can do all the things mentioned in C. C. section 2430 and U. P. A. section 9 (3) respectively. The Civil Code requires that the business be abandoned to the remaining partner, but the cases do not construe this as requiring something akin to a conveyance; and therefore in both the rule would seem to be the same..$^{54}$.

The Code also prescribes the same rule when one partner becomes incapable of acting. The U. P. A. requires an application to a court before the other has enlarged rights under section 32 ( 1 , subdiv. a). In the case of abandonment the remaining partner has a right to take a chance without such an application. It would seem that he can judge better whether there has been an abandonment than whether his partner is of unsound mind. For the protection of the unsound in mind application to a court seems desirable.

With regard to assignments of partnership property, the lack of authority expressed in the Code does not extend to cases where the assignment is not strictly in trust but is made upon the assignee's promise to pay the partnership debts. On the other hand, the U. P. A. does not declare a lack of authority as to assignments of partnership properly to a creditor. It would seem that the rules laid down in the U. P. A. are preferable. Seemingly, under the Code, a single pariner could never pay a debt of the firm in any way that amounted to an assignment of property, that

54 California cases on subject of abandonment: Mere temporary absence from state is not, Carrie v. Cloverdale Banking and Commercial Co. (1891) 90 Cal. 84, 27 Pac. 58; when one partner absconded it was held the remaining partner had the rights of a surviving partner; Depuy v. Leavenworth (1861) 17 Cal. 262; facts showed intention to abandon, Quinn v. Quinn (1889) 81 Cal. 14, 22 Pac. 264. 
is, no firm creditor can safely take payment in goods from one partner..$^{55}$

Again, the Code impliedly permits the assignment of all the property of the partnership if it consists entirely of merchandise. This is confusing. ${ }^{56}$ Nearly always a firm has a good-will besides tangible property. Such good-will would seem to be "property" (C. C. section 993), thus possibly rendering the section inapplicable in such a case. Furthermore, an assignment even of merchandise may violate the next subsection of the code. The U. P. A. in omitting the clause in question (C. C. section 2430, subdiv. 3) avoids this confusion. The vital thing is that expressed both in C. C. section 2430 (4) and U. P. A. section 9 (3) (c). On the contrary, the clause of the U. P. A. just referred to uses the word "other", which seemingly adds nothing, for may not good-will be disposed of, as by a sale of business site and name, and yet the partnership somewhere else under a different name continue its ordinary business? The question naturally occurring is whether or not the framers of the U. P. A. have not shown a disposition to regard the continued business in such a case as done by a new partnership. This would hardly seem to be the case and might work harm to firm creditors.

Clause (e) of U. P. A. section 9 (3) amplifies the phraseology of the corresponding subsection of the Code (C C. section 2430, subdiv. 6) by adding the words "or reference", provisions for which exist in C. C. P. sections $638 \mathrm{ff}$ ).

Subsection (4) of U. P. A. section 9 raises a question; does it cover the case where the act done is apparently in the usual way of business of the partnership whose members are made defendants. but where in fact there is also an agreement between the partners that the particular act shall not be done by the active partner? If so, it would seem that it merely reaffirms U. P. A. section 9 (1). It is true that the subsection (1) refers to "no authority" and subsection (4) to "restriction on .... authority",

55 But cf. Pacific Mut. L. I. Co. v. Fisher (1895) 109 Cal. 566, 42 Pac. 154; Dupuy v. Leavenworth (1861) 17 Cal. 262. How would a case like Forbes v. Scannell (1859) 13 Cal: 242, be decided under U. P. A. \$ 9 (3) (a) or C. C. $\$ 2430$ (1)? There one partner in the Orient was held to have authority to make an assignment for benefit of creditors in the absence of the others, although they had not abandoned the business. The circumstances were peculiar and the result seems justified. How rigid are the rules stated in U. P. A. \& 9 (3) ? They should not be unbendable. Codification often tends to inflexibility. But here the danger is not increased, since we already have a code.

${ }_{50} \mathrm{Cf}$. Crites v. Wilkinson (1884) $65 \mathrm{Cal}$. 559, 4 Pac. 567, holding cattle to be merchandise with Myers v. Moulton (1886) 71 Cal. 498, 12 Pac. 505, holding that a stallion was not merchandise under C. C. $\$ 2430$ (3). 
but it would seem that if an act falls within the limits of a restriction then as to that act there is no authority. A court should not strain to read an exotic meaning into one subsection because outwardly it is so like the other, on the theory that a legislature is so wise that it can never be admitted to have committed the sin of repetition. Rather should the court say, in effect, that the legislature may have placed two sign-posts giving the same directions on the same corner with only slight variation in phraseology in order to prevent the court's being lost if it misses or does not understand one.

How would a court faced with these two subsections decide a case where parties make an agreement and do business in such a way that they become partners in fact, but in their agreement also provide that one partner shall never be liable for the acts of the others? Of course in such a case it is not agreed that these others shall not do the ordinary acts-not agreed that they shall have no authority to do them. Suppose, further, that a third party, knowing of this term, contracts with these others acting for the firm; can he hold the first partner? It would seem that this case comes within neither of the subsections. The first partner should be liable unless there can be found an agreement not to sue him. ${ }^{57}$

It should be noticed that knowledge of the restriction, not of its terms, bars the third party's right. This has already been held in California. ${ }^{58}$

The U. P. A., like the Civil Code, does not formulate the distinction between the power of one partner to bind a trading firm for his borrowings and his power to bind a non-trading firm. ${ }^{59}$ Nor does it interfere with the freedom of a partner to contract in his own name though on firm business if he so desires. ${ }^{60}$

This is one of the few sections that has received judicial construction. ${ }^{61}$

XVI. Conveyance of Real Property of the Partnership.

U.P. A. Section 10. (1) Where title to real property is in the partnership name, any partner may convey title to such property by a conveyance executed in the partnership name; but the partnership may recover such property unless the partner's act binds the partnership under the provisions of

57 See Streeter \& Riddell v. Bacon (1920) 33 Cal. Cal. App. Dec. 197, to be commented upon in the March number of this Review.

${ }_{53}$ Hill y. Maryland Casualty Co. (1910) 12 Cal. App. 461,107 Pac. 707.

59 Burdick, Partnership (3d. ed.) 192 ff.

oo Brown v. Fresno Raisin Co. (1894) 101 Cal. 222, 35 Pac. 639.

61 Bank of Bellebuckle v. Mason (1918) 139 Tenn. 659, 202 S. W. 931. 
paragraph (1) of section 9, or unless such property has been conveyed by the grantee or a person claiming through such grantee to a holder for value without knowledge that the partner, in making the conveyance, has exceeded his authority.

(2) Where title to real property is in the name of the partnership, a conveyance executed by a partner, in his own name, passes the equitable interest of the partnership, provided the act is one within the authority of the partner under the provisions of paragraph (1) of section 9.

(3) Where title to real property is in the name of one or more but not all the partners, and the record does not disclose the right of the partnership, the partners in whose name the title stands may convey title to such property, but the partnership may recover such property if the partners' act does not bind the partnership under the provisions of paragraph (1) of section 9, unless the purchaser or his assignee, is a holder for value, without knowledge.

(4) Where the title to real property is in the name of one or more or all the partners, or in a third person in trust for the partnership a conveyance executed by a partner in the partnership name, or in his own name, passes the equitable interest of the partnership, provided the act is one within the authority of the partner under the provisions of paragraph (1) of section 9.

(5) Where the title to real property is in the names of all the partners a conveyance executed by the partners passes all their rights in such property.

Parallel reference: none.

(1) This subsection changes substantially the law of California but seemingly not in a way that will result in any unjust consequences. In brief it provides that real property may be received and conveyed in the partnership name. Today a conveyance stating as grantee the firm name vests a legal title only in the partners whose names appear in the firm name, ${ }^{62}$ or if none of their names appear there, only an equity to demand a deed conveying a legal title. ${ }^{63}$ From the point of view of partnership law the conversion of these equities into legal interests is certainly highly desirable, responding to the intent of the parties as the present rules do not. From the point of view of the conveyancer, however, the rule of the U. P. A. is not so desirable, because it is probable that to link up a chain of title it will be necessary to

62 Holding that a deed or mortgage of real estate to " $\mathrm{X}$ and Co." carries no title to the firm (all the partners) but only to the one or ones whose name or names appear in the firm name: Woodward v. McAdam (1894) 101 Cal. 438, 35 Pac. 1016; Winter v. Stock (1866) 29 Cal. 408.

es Burdick, p. 100 . 
resort to matters outside the record oftener than at present. ${ }^{64}$ Indeed this factor has perhaps been one reason for the vitality of the rules now existing, which apply only to real estate. It has long been settled that the firm name is sufficient to describe a transferor or transferee of personality. ${ }^{65}$

(2) Subsection (2) is objectionable in one minor point. Suppose a partnership deals in real estate and has partnership property in the firm name. Does this section mean that a conveyance by a single partner in his own name carries more than his right after an accounting? By itself the section would justify such a conclusion, but the unexpressed supposition as to the conveyance being necessarily one on behalf of the firm can be supplied by a reading of this subsection in connection with the last clause and the rest of the act.

(3) Subsection (3) will work no change in California law, unless the phrase "and the record does not disclose the right of the partnership" alters the rule that a mere descriptio personarum can be disregarded. Does a statement that the grantees A and B are "partners under the firm name of $A$ and Co." disclose the right of the partnership? It would not do so before the adoption of the Uniform Act. It should not do so under that Act, because although subsection (1) does give a new validity to the firm name. it does not apply to this case. ${ }^{66}$

Subdivisions (4) and (5) are self-explanatory.

The case upon which U. P. A. section 10 is not wholly clear is that where a grant of real estate is made to a partnership in the firm name, and then is conveyed by a deed signed by all the partners individually. The conveyancer's difficulty in tracing a chain of title is recognized and perhaps removed by U. P. A. section 8 (3), which provides that in such case the title does not pass. Presumably, however, a right to compel a conveyance does pass under U. P. A. section 10 (2).

For comparison, some typical California cases are cited in the

$64 \mathrm{Mr}$. Crane also suggests that to make this workable an amendment of the acknowledgement laws is necessary so as to make it appear of record that a person executing a deed in the partnership name is a partner and is authorized to convey, 28 Harvard Law Review, 779 . But Mr. Lewis declares that a deed would be sufficient to protect a purchaser having no notice without these facts appearing, 29 Harvard Law Review, 298. Mr. Lewis seems to have the best of it on the phraseology of the act. 218.

6s Hendren v. Wing (1895) 60 Ark. 561, 31 S. W. 149, 46 Am. St. Rep.

${ }^{66} \mathrm{~A}$ bona fide purchaser of real estate, legal title to which was in the name of one partner, obtained a good title in McNeil v. Congregational Society (1884) 66 Cal. 105, 4 Pac. 1096. 
note. In most the same result would be reached under the U.P. A. but on different theories. ${ }^{67}$

\section{Partinership Bound by Admission of Partner.}

U. P. A. Section 11. An admission or representation made by any partner concerning partnership affairs within the scope of his authority as conferred by this act is evidence against the partnership.

Parallel reference: Cf. C. C. P. § 1870.

Although there are few or no California decisions on this subject it cannot be doubted that this is the law of the state, except in a connection to be noticed under U. P. A. section 14 , infra. ${ }^{68}$

\section{Partnership Charged With Knowledge of a Notice} to Partiner.

U. P. A. Section 12. Notice to any partner of any matter relating to partnership affairs, and the knowledge of the partner acting in the particular matter, acquired while a partner or then present to his mind, and the knowledge of any other partner who reasonably could and should have communicated it to the acting partner, operate as notice to or knowledge of the partnership, except in the case of a fraud on the partnership committed by or with the consent of that partner.

Parallel reference: Cf. C. C. $\$ 2431$.

This section should be read in the light of the definitions of notice and knowledge contained in U. P. A. section 3, paragraph VIII, above.

So far as "notice" is concerned the section does not seem to be open to criticism, but there is an ambiguity latent in the word "then" in the phrase "acquired while a partner or then present to his mind." The natural antecedent of the word "then" is the phrase "while a partner"-that is, if a man having knowledge of a fact later becomes member of a partnership, later still thinks of this fact, and then forgets it, the partnership is charged with such

67 Holding that a deed of real estate to partners vests title in them as tenants in common: Grant v. Bannister (1911) 160 Cal. 774, 118 Pac. 253; Shirran v. Dallas (1913) 21 Cal. App. 405, 132 Pac. 454, 462; but that holders of legal title are trustees for firm: Duryea v. Burt (1865) 28 Cal. 569; Doudell v. Shoo (1912) 20 Cal. App. 424, 129 Pac. 478; even when the property originally belonged to one partner if used as firm property: Wiegand v. Copeland (1882) 14 Fed. 118; that real estate must be treated as personal property and sold: Moran v. McInerney (1900) $129 \mathrm{Cal}$. 29. A consequence of the rules stated in the above note is that a grantee of one partner may maintain ejectment against the other partners even though he had notice of the firm and they can defeat his right only by an affirmative showing that the property is needed for firm obligations: McCauley $v$. Fitton (1872) 44 Cal. 355. A different result would be reached under U. P. A. \& 25 .

68 See on this section, Burdick, Partnership (3d. ed.) 202. 
knowledge even though the man acts without remembering it at all. The commissioners' note seems to relate the word "then" not to the indefinite period of partnership membership but to the period of doing the particular act with reference to which it is sought to charge the partnership with knowledge. This is the preferable rule, but the Act does not seem to cover this case with sufficient clearness. It is a minor point, however, and the remaining rules here enunciated fill a gap in California law not already filled by decision or Code provisions.

XIX. Partnership Bound by Partner's Wrongrul Act.

U.P.A. Section 13. Where, by any wrongful act or omission of any partner acting in the ordinary course of the business of the partnership or with the authority of his copartners, loss or injury is caused to any person, not being a partner in the partnership, or any penalty is incurred, the partnership is liable therefor to the same extent as the partner so acting or omitting to act.

Parallel references: C. C. $\$ \$ 2442,2443$.

The liability supposed by this section is evidently that which sounds in tort, although the word "wrongful" is of general import. The question whether it might be extended to cover breaches of contract becomes important in connection with U P. A. section 15 . There seems no reason why the term "tort" should be thrown by the board, and a certain degree of ambiguity results from not using it, but taking the words in this section in connection with the rest of the section and with U. P. A. section 15 making liability under this section joint and several in contradistinction to the joint liability under, for instance, U. P. A. section 9, and in view of the fact that partnership tort liability is usually joint and several, it would seem that tort liability is here intended.

If so, no great change is worked in our law. The liability in tort depends upon C. C. section 2443 which refers to the title on agency. U. P. A., section 13 predicates tort liability on principles of agency. The one matter as to which this section may change the law will be discussed under the next section.

XX. Partnership Bound by Partner's Breach of Trust.

U.P.A. Sectron 14. The partnership is bound to make good the loss:

(a) Where one partner acting within the scope of his apparent authority receives money or property of a third person and misapplies it; and

(b) Where the partnership in the course of its business receives money or property of a third person and the money 
or property so received is misapplied by any partner while it is in the custody of the partnership.

Parailel references: none.

The commissioners offer no explanation of this section. Assuming that $U$. P. A. section 13 creates and governs liability in tort (wrongful acts and omissions) and that U.P. A. section 15 gorerns the nature of the liabilities so created, there would seem offhand to be no necessity for U. P. A. section 14. But the section does in fact serve to establish a uniform rule in a matter where other states have differed, although not yet mooted here. ${ }^{69}$

The section, however, is objectionable in a minor point just as U. P. A. section 9 is objectionable, that is, in the use of the word "apparent" without referring it to an object. Again, what is the custody of the "partnership"? Is it custody at the usual place of business or not?

Another matter of interest to Californians is as to the effect of this section and the preceding one upon the liability of one partner for another's deceit. Generally, if that deceit were according to the usual rules of principal and agent within the scope of the active partner's authority, the non-active partner would be liable. It frequently happens, however, that the same evidence that establishes the deceit also shows the act not to have been within the scope of the active partner's authority, and therefore the act does not bind the non-active partner. Some California judges have "apparently" been confused by this consideration and instead of making an inquiry into the question of authority have seemingly excused the non-active partner because he personally committed no fraud. ${ }^{70}$ This is opposed to the theory of liability imposed under C. C. section 2443. Would California judges continue this opposition under U. P. A. section 13 ? Certainly they should not, and yet U. P A. section 13 is not more apt in this connection than $C$. C. section 2443. If, however, the fraud brought the case within the terms of U. P. A. section 14 , no doubt could arise as to the non-active partner's liability. This would apply to the dictum in Gibson v. Henley, and change the law so far as it is expressed in that dictum. Since the other California case antedates the Civil Code, it seems likely that the U. P. A. would bring us into line with the majority view.

${ }^{69}$ See Dammon v. Beecher (1893) 97 Cal. 530, 32 Pac. 573; Burdick, Partnership (3d. ed.) 221 ff.

70 Stewart v. Levy (1868) 36 Cal. 159; Gibson v. Henley (1900) 131 Cal. 61, 63 Pac. 61 ; but cf. Corson v. Berson (1890) 86 Cal. 433, 25 Pac. 7; Grossini v. Perazzo (1885) 66 Cal. 545, 6 Pac. 450. 
XXI. Nature of Partiner's Liability.

U. P. A. Secrion 15. All partners are liable

(a) Jointiy and severally for everything chargeable to the partnership under sections 13 and 14.

(b) Jointly for all debts and obligations of the partnership; but any partner may enter into a separate obligation to perform a partnership contract.

Parallel references: C. C. section 2442.

The effect of this section would seem to make liability sounding in tort joint and several and liability sounding in contract joint. Our law is probably the same. C. C. section 2442 makes partners jointly liable for "obligations" of the partnership..$^{72}$ Even though the term "obligations" might have been stretched to cover tort liabilities, this has not been done. ${ }^{72}$

How do the rules here laid down square with the remedies given under C. C. P. sections 388 and 414 ? Though the liability on firm contracts is joint, and these sections really permit the enforcement of such obligation as though that liability were several, the change, common to many states, is only precedural after all. The commissioners state that this section is not intended to affect statutes of the nature of C. C. P. sections 388 and 414 . If their true nature, as procedural only, be kept in mind, U. P. A. section 15 can coexist harmoniously with them and it will not be necessary to save them specifically from the operation of the U. P. A. If they are more than procedural, the enactment of the U. P. A. would restore them to their proper procedural basis. It is true that they have been, probably quite erroneously, looked upon as more than procedural. $^{73}$ If a saving clause added to the $U$. $P$. A. to save these sections of the Code of Civil Procedure saves with it these erroneotis decisions, the law will only be confused and the purpose of the U. P. A. partly defeated.

While partners are declared to be jointly liable for contracts

71 Rose v. Feldman (1885) 67 Cal. 100, 7 Pac. 185; Miner v. Rickey (1907) 5 Cal. App. 451, 90 Pac. 718; Baker v. Lambert (1907) 5 Cal. App. 708, Pac. 340; Iwanaga v. Hagopian (1919) 39 Cal. App. 584, 179 Pac. 523. But in this connection it should be recalled that the obligations of joint promisors are affected by other provisions of C. C., e. g., $\$ 1543$ providing that a release of one does not release others, Northern Ins. Co. v. Potter (1883) $63 \mathrm{Cal}$. 157. The adoption of U. P. A. should not be regarded as affecting such provisions.

72 Rogers v. Ponet (1913) 21 Cal. App. 577, 132 Pac. 851; Murphy v. Coppieters (1902) 136 Cal. 317, 68 Pac. 970.

${ }_{73}$ Artana v. San José Scavenger Co. (1919) 58 Cal. Dec. 508, 185 Pac. 850; commented upon in 8 California Law Review, 265. See also Asbestos Manufacturing etc. Co. v. Lennig-Rapple Eng. Co. (1914) 26 Cal. App. 177, 182, 146 Pac. 188; The John Bollman Co. v. S. Bachman \& Co. (1911) 16 Cal. App. 589, 117 Pac. 690, 122 Pac. 835. 
and jointly and severally liable for torts, etc., how are partnership rights owned? Upon this point the U. P. A. is silent, and presumably California cases that have to consider questions of mis- and non-joinder and the like when suit is brought on a promise to the partnership stand unaffected. ${ }^{74}$ The same would also seem to be as true as to torts to partnership property with such modifications as are necessary in the case of real estate now held as tenants in common, but under the act to be held at tenants in partnership..$^{75}$ These modifications, broadly speaking, would make the promise like that held by persons jointly, releasable by one, passing to the survivor, and so forth.

\section{PARTNER BY EstopPeL.}

U.P.A. Section 16. (1) When a person, by words spoken or written or by conduct, represents himself, or consents to another representing him to any one, as a partner in an existing partnership or with one or more persons not actual partners, he is liable to any such person to whom such representation has been made, who has, on the faith of such representation, given credit to the actual or apparent partnership, and if he has made such representation or consented to its being made in a public manner he is liable to such person, whether the representation has or has not been made or communicated to such person so giving credit by or with the knowledge of the apparent partner making the representation or consenting to its being made.

(a) When a partnership liability results, he is liable as though he were an actual member of the partnership.

(b) When no partnership liability results, he is liable jointly with the other persons, if any, so consenting to the contract or representation as to incur liability, otherwise separately.

(2) When a person has been thus represented to be a partner in an existing partnership, or with one or more persons not actual partners, he is an agent of the persons consenting to such representation to bind them to the same extent and in the same manner as though he were a partner in fact, with respect to persons who rely upon the representation. Where all the members of the existing partnership consent to the representation, a partnership act or obligation results; but in all other cases it is the joint act or obligation

74 Cf. Nightingale v. Scannell (1856) 6 Cal. 506, 65 Am. Dec. 525; A. M. Gilman \& Co. v. Cosgrove (1863) 22 Cal. 356; Jaumann v. McCusick (1913) 166 Cal. 517, 137 Pac. 254; Lucas y. Gobbi (1909) 10 Cai. App. 648, 103 Pac. 157; Williams v. Southern Pacific Co. (1895) 110 Cal. 457, 42 Pac. 974.

is See par. XXXIII, to appear. 
of the person acting and the persons consenting to the representation.

Parallel references: C. C. $\S \S 2444,2445$; Cf. $\S 2431$.

That one who consents to his being held out or holds himself out as a partner ought to be liable to some extent when the other requisites of an estoppel are present is universally admitted. ${ }^{26}$ The difficult question is how far this liability carries with it the incidents of partnership liability. For example, is a creditor whose rights depend on estoppel entitled to the status of a firn creditor? These questions may have caused difficulty in California, and if so, those difficulties are not cured either by decided cases or by the provisions of the Code. The section of the Civil Code upon this subject is full of ambiguities. Does the phrase "represented as a partner" mean represented as a partner is represented, that is by the other partners or by agents? The section says so, but probably means something quite different in view of the fact that "represented" is later used in the sense of making a statement of fact. In other words, the term "as a partner" must mean "to be a partner". Assuming this to be true, we are next troubled with the question whether a man is liable as a partner when (1) he is represented to be a partner in an existing partnership (a) by all the actual partners, (b) by several of them, or (c) by one not in fact a partner (hinself or a stranger) ; or (2) when he is represented to be a partner in a firm not existing in fact (a) by the other supposed member or members of the firm, (b) by several of them, or (c) by himself or a stranger. There are thus six possible situations, and possibly more. They are apparently all treated alike in the Code and yet the result should obviously not be the same in all the cases.

Of course C. C. section 2444 may not intend to give the words "as such" any effect as against third parties, creditors of the firm $_{2}$ if there is one, or of the other individuals, who seek to compete with persons relying on the section, if there is no firm. If so, the Code is silent upon the most important question of all. It would seem that this is not the intent of the Code. The words "as such" must mean "as a partner", not merely "as an individual."

${ }^{76}$ Crawford v. Indep. Stove Pipe Works (1890) 83 Cal. 629, 24 Pac. 836; Reubin v. Cohen (1874) 48 Cal. 545; Skillman v. Lachman (1863) 23 Cal. 198, 83 Am. Dec. 96; Smith v. Hill (1883) 63 Cal..50. That U. P. A. $\$ 16$ (1) requires stricter proof than the British Act, see Burdick Partnership (3d. ed) 72. A corporation may be estopped to deny that it is not a partnership, Gnarini v. Banca Svizzera Americana (1918) 39 Cal. App. 200, 178 Pac. 532. 
Only when the representation is made by all the members of an existing firm has the estoppel-asserter any show of right in contending that he should be treated as actual firm creditors are treated, for then the estoppel-asserter claims through the same persons as those through whom the actual firm creditors claim. This is case 1 (a) above, and is so provided in U. P. A. section 16 (2), the last sentence. In all the other cases the estoppelasserter should not be entitled to share equally with the firm creditors or ahead of the separate creditors of those responsible for the representation. To reach these results, however, requires reading varying subjects of the passive verb in C. C. section 2444 .

It has been seen that U. P. A. section 16 is clear in this particular. It also provides that in the other cases, there is no right entitling the estoppel-asserter to share with the actual firm creditors (U. P. A. section 16 (2), last clause of last sentence). The persons responsibile for the estoppel are, however, liable jointly under subsections (1) and (6) of U. P. A. section 16. This joint liability would not entitle him to priority. ${ }^{77}$

\section{Liability of Incoming Partner}

U.P.A. Section 17. A person admitted as a partner into an existing partnership is liable for all the obligations of the partnership arising before his admission as though he had been a partner when such obligations were incurred, except that this liability shall be satisfied only out of partnership property.

Parallel reference: none.

The commissioners in a long note explain in effect, that the purpose of this section in connection with U. P. A. section 41 is to preserve the rights of creditors of an old firm when a new one has been created by an unostentatious change in membership. Their rights have been preserved sometimes by a finding, very forced, of an assumption of the old debts by the new firm. The section in question, by visiting upon an incoming partner certain liabilities with reference to debts of the old firm, takes away one ground for making objection to liability of the assets of the new firm to the old debts when no such assumption is justified.

It must be admitted that this is legislation which will clrange

77 See Whelan v. Shain (1896) 115 Cal. 326, 47 Pac. 57. But for an argument that the act does not accomplish its purpose in excluding the estoppel-asserter from claiming as a firm creditor, see Mr. Crane, $28 \mathrm{Har}-$ vard Law Review, 780. This is fully answered by Mr. Lewis, 29 id. 300. 
existing law. The matter will be discussed more fully under U. P. A. section $41 .^{i 8}$

XXIV. Relations of Partners to One Another.

This topic in the U. P. A. (sections 18-23) comes after that relating to the liability of partners to third persons (sections 9-17); whereas in the Civil Code the order is just reversed. Since the creditors in general are preferred to partners, the arrangement in the U. P. A. would seem to be the more scientific.

A. T. Wright.

University of California

Berkeley, California.

(To Be Continued.)

${ }^{78}$ See par. L, to appear. 